\title{
Dandelion T-1 extract up-regulates reproductive hormone receptor expression in mice
}

\author{
XU ZHI, KEN-ICHI HONDA, KOJI OZAKI, TAKUYA MISUGI, TOSHIYUKI SUMI and OSAMU ISHIKO
}

Department of Obstetrics and Gynecology, Osaka City University Graduate School of Medicine, 1-4-3 Asahimachi, Abeno-ku, Osaka 545-8585, Japan

Received April 10, 2007; Accepted May 21, 2007

\begin{abstract}
Reproductive hormones exert their actions via receptors in diverse tissues. In this study, we examined the expression of estrogen receptors (ER $\alpha$ and $E R ß)$, progesterone receptor (PR), and follicle-stimulating hormone receptor (FSHR) in the adipose tissue and reproductive organs of mice following oral treatment with Dandelion T-1 extract (DT-1E) for 6 weeks. Quantitative assays by real-time reverse transcription polymerase chain reaction showed enhanced expression of ER $\alpha$ and ERß mRNA in the adipose tissue of mice fed a diet containing DT-1E compared with the control group fed a plain diet. Furthermore, following gonadotropin injection, higher mRNA expression of $\mathrm{ER} \alpha, \mathrm{ER} \beta$ and $\mathrm{PR}$ in the uterus and FSHR in the ovary was found in the DT-1E group compared with the control group. An immunohistochemical study also showed increased levels of the abovementioned receptors in the DT-1E group. The present study shows that oral intake of DT-1E up-regulates ER $\alpha, E R \beta, P R$ and FSHR expression in mice, suggesting the potential application of DT-1E for the clinical treatment of reproductive hormone-related disturbances.
\end{abstract}

\section{Introduction}

Reproductive hormones, such as estrogen, progesterone and follicle-stimulating hormone, have been found to be correlated with various biochemical and physiological processes, and are also implicated in a wide range of disorders and diseases in women, such as menopausal symptoms, obesity, and several types of cancer (1-3). Regulating hormone levels has been regarded as the usual means of clinical treatment of hormone-related disturbances. For instance, it is well known that hormone replacement therapy (HRT) is effective for the

Correspondence to: Dr Ken-ichi Honda, Department of Obstetrics and Gynecology, Osaka City University Graduate School of Medicine, 1-4-3 Asahimachi, Abeno-ku, Osaka 545-8585, Japan

E-mail: kenhonda@med.osaka-cu.ac.jp

Key words: estrogen receptor $\alpha$, estrogen receptor $\beta$, progesterone receptor, follicle-stimulating hormone receptor, Dandelion T-1 extract, mouse alleviation of menopausal symptoms; however, it carries a risk of dose-related side effects $(4,5)$. In addition, hormones exert their actions via corresponding receptors $(6,7)$ and, therefore, investigating receptor expression may help to clarify the pathophysiological states induced by hormones, and may even contribute to alternatives to currently available hormone therapies with less inconvenience or risk.

In this respect, herbal products have recently become increasingly popular, and they are used widely for their promising therapeutic effects and fewer side effects. A number of therapies of herbal origin have been utilized to treat reproductive hormone-related disturbances in women (8-10), although the detailed mechanisms of their actions remain to be elucidated. We hypothesized that the therapeutic effects of these herbal products could possibly be associated with an influence on reproductive hormone levels or the expression of their receptors.

In the present study, we adopted one of the commercially available herbal products, Dandelion T-1 extract (DT-1E), and investigated the variations in serum hormone levels and the expression of estrogen receptors (ER $\alpha$ and ERß), progesterone receptor (PR), and follicle-stimulating hormone receptor (FSHR) in adipose tissue, the uterus and the ovary of female mice, as well as its effect on ovulation, after intake of a diet containing DT-1E for 6 weeks.

\section{Materials and methods}

Animals and diets. All conditions and handling of animals were conducted according to the Guidelines for Animal Experimentation of Osaka City University, and the study was approved by our institutional Animal Research Committee. Thirty-six female $\mathrm{C} 3 \mathrm{H} / \mathrm{HeNCrlCrlj}$ mice (4 weeks old) were purchased from Charles River Laboratories Japan, Inc. (Yokohama, Japan). The mice were randomly assigned to 4 groups ( $\mathrm{n}=9$ for each group) and individually housed in cages maintained at a constant temperature $\left(23 \pm 1^{\circ} \mathrm{C}\right)$ and humidity $(55 \%)$ with a $12: 12$-h light-dark cycle. The mice had free access to food and water throughout the whole 6-weekfeeding period. Two control groups of mice were given a phytoestrogen-free plain diet (NIH-07PLD; Oriental Yeast Co., Ltd., Tokyo, Japan), and the two DT-1E groups were fed a diet containing $0.03 \%$ (w/w) DT-1E (Wellness Advance Institute, Osaka, Japan). DT-1E consists of $87 \%$ dandelion extract, $5 \%$ adlay, $5 \%$ sucrose, and $3 \%$ ant extract. 
A
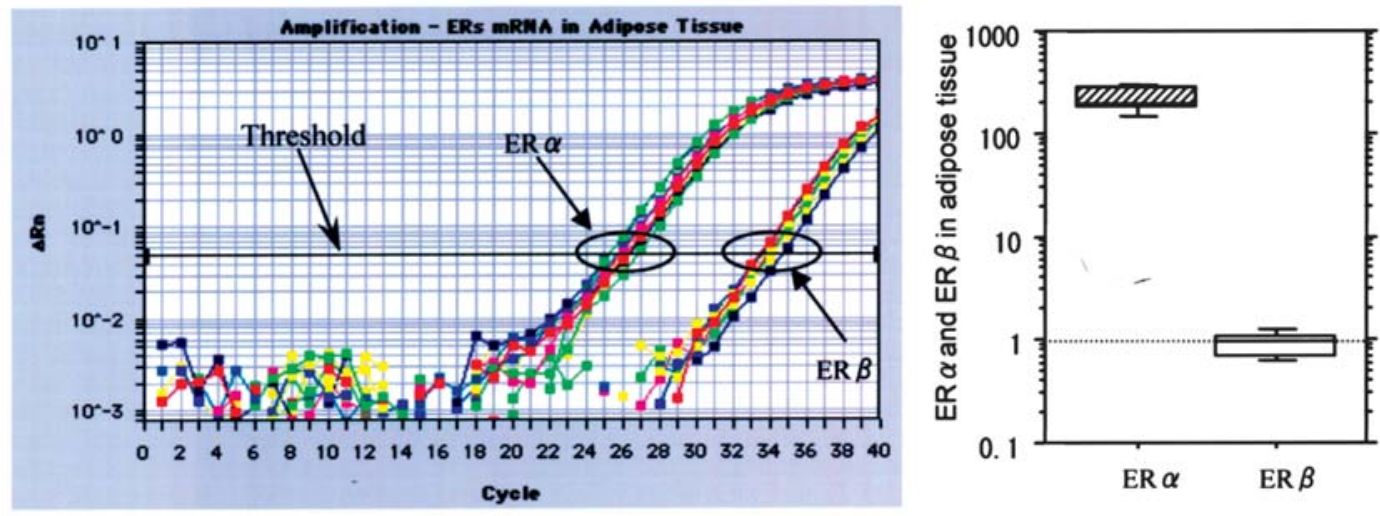

B
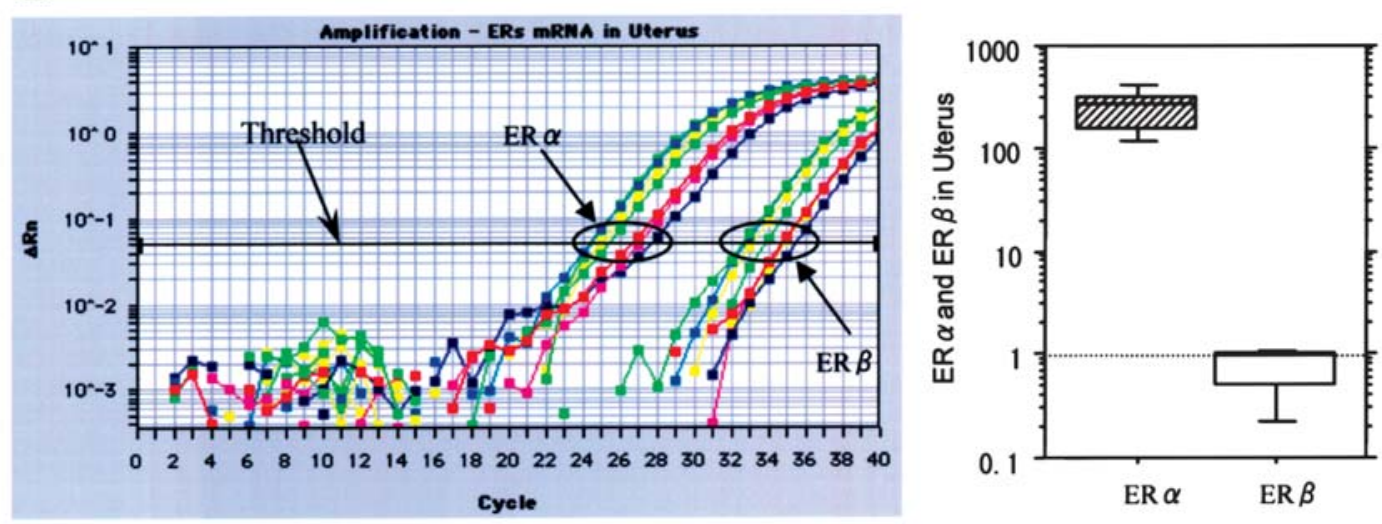

Figure 1. Quantification of ER $\alpha$ and ERß mRNA in adipose tissues and uteri of mice fed a plain diet, without gonadotropin injection. The solid line represents the threshold, and the $\mathrm{x}$-axis indicates the threshold cycle $\left(\mathrm{C}_{\mathrm{T}}\right) . \mathrm{C}_{\mathrm{T}}$ is the number of amplification cycles when the PCR products reach the threshold. Since $\mathrm{ER} \alpha$ presented smaller $\mathrm{C}_{\mathrm{T}}$ values, it showed a greater amount of mRNA compared with ERß in both adipose tissues (A) and uteri (B). The amount of ER $\alpha$ and $\mathrm{ER} ß \mathrm{mRNA}$ determined with the $\Delta \Delta \mathrm{C}_{\mathrm{T}}$ method is shown as box-plots on the right side.

Mice in one of the two control groups and one of the DT$1 \mathrm{E}$ groups were treated with gonadotropin injection at an age of 10 weeks. For gonadotropin injection, each mouse was given a single intraperitoneal injection of 5 IU pregnant mare's serum (PMS, G4527; Sigma, St. Louis, MO, USA) diluted in $0.1 \mathrm{ml}$ sterilized normal saline. Forty-six hours later, another single intraperitoneal injection of 5 IU human chorionic gonadotropin (hCG, C8554; Sigma), diluted in $0.1 \mathrm{ml}$ sterilized water, was administered. Twelve hours after the injection of hCG, all mice, including the other two groups without gonadotropin injection, were sacrificed by ether inhalation, and parametrial adipose tissues, uteri and ovaries were dissected.

Serum hormone assay. During dissection of the mice, blood samples were obtained from the abdominal aorta, and the serum estradiol level was determined by radioimmunoassay (RIA) using a kit from Diagnostic Products Corporation (Los Angeles, CA, USA) with a limit of detection of $1.4 \mathrm{pg} / \mathrm{ml}$ and intra- and inter-assay variation coefficients of $1.75 \%$ and $2.58 \%$, respectively.

RNA isolation, reverse transcription, and quantitative realtime PCR. Total RNA was isolated from the adipose tissues, uteri and ovaries of mice using an RNeasy Protect mini kit (Qiagen, Valencia, CA, USA), according to the manufacturer's instructions. The isolated total RNA was stored at $-80^{\circ} \mathrm{C}$ before further processing.

Two-step quantitative real-time reverse transcription polymerase chain reaction (real-time RT-PCR) was performed to measure mRNA levels. Total RNA samples were reverse transcribed into cDNA using TaqMan reverse transcription reagents (Applied Biosystems, Foster City, CA, USA). One microgram of each total RNA sample was added into a reverse transcriptase mixture, prepared in accordance with the TaqMan Gold RT-PCR protocol, giving a final volume of $100 \mu 1$. The reverse transcription reactions were performed at $25^{\circ} \mathrm{C}$ for $10 \mathrm{~min}, 37^{\circ} \mathrm{C}$ for $60 \mathrm{~min}$ and, finally, $95^{\circ} \mathrm{C}$ for $10 \mathrm{~min}$.

TaqMan quantitative real-time PCR was performed in a $50-\mu 1$ reaction mixture on an ABI PRISM 7700 sequence detector system (Applied Biosystems) according to the manufacturer's instructions, using appropriate primers and probes with a 6-carboxyfluorescein-labeled 3'-minor groove binder for cDNA encoding ER $\alpha$ (Mm00433153_m1), ERß (Mm00599821_m1), PR (Mm00435628_m1), and FSHR (Mm00442819_m1) (Applied Biosystems). The oligonucleotide sequences are not publicly available, but they were validated by the manufacturer.

Quantification of mRNA transcripts was carried out by the comparative $\mathrm{C}_{\mathrm{T}}\left(\Delta \Delta \mathrm{C}_{\mathrm{T}}\right)$ method. The amount of target, normalized to an endogenous reference, 18S rRNA (Applied Biosystems), and relative to a calibrator, was determined by 


\section{A}

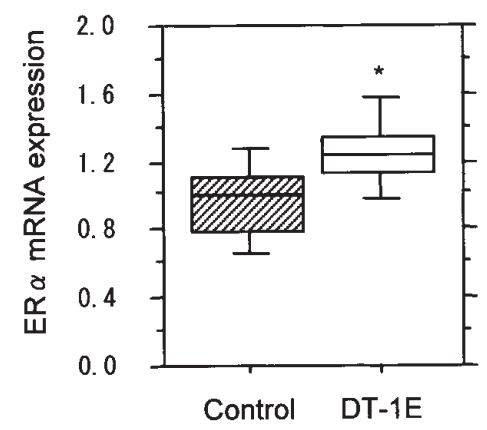

B

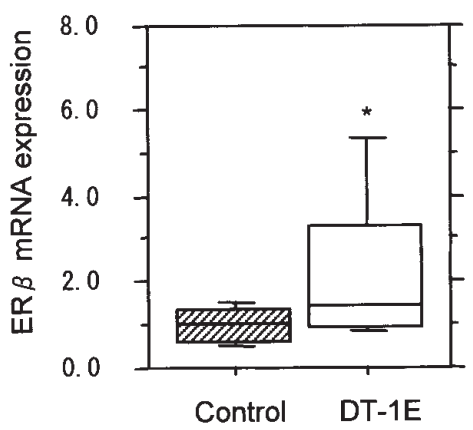

Figure 2. Expression of ER $\alpha$ and ERß mRNA in mouse adipose tissues in DT-1E and control groups without gonadotropin injection. Quantitative assays by TaqMan real-time RT-PCR showed that the expression of both $\mathrm{ER} \alpha(\mathrm{A})$ and ERß (B) mRNA in mouse adipose tissues was significantly higher in the DT-1E group than in the control group $\left({ }^{*} \mathrm{P}<0.05\right)$ after oral intake of DT-1E for 6 weeks. Values are expressed as fold-change compared to levels observed in the control group.

evaluating the expression 2- $\Delta \Delta \mathrm{CT}$ (11-13), where $\Delta \Delta \mathrm{C}_{\mathrm{T}}=\Delta \mathrm{C}_{\mathrm{T}, \mathrm{s}}$ - $\Delta \mathrm{C}_{\mathrm{T}, \mathrm{cb}} \cdot \mathrm{C}_{\mathrm{T}}$ is a numerical value given as a parameter by $\mathrm{ABI}$ PRISM 7700 sequence detector software, having a negative correlation with the initial amount of mRNA in the reaction system; $\Delta \mathrm{C}_{\mathrm{T}}$ is the difference in threshold cycles between the target and reference; $\Delta \mathrm{C}_{\mathrm{T}, \mathrm{s}}$ is the $\Delta \mathrm{C}_{\mathrm{T}}$ value of a sample; and $\Delta \mathrm{C}_{\mathrm{T}, \mathrm{cb}}$ is that of the calibrator (median of the control group).

Immunohistochemistry of adipose tissue and reproductive organs. For immunohistochemistry of ER $\alpha, E R \beta, P R$ and FSHR, paraffin-embedded sections (4- $\mu \mathrm{m}$ thick) of adipose tissues, uteri and ovaries of mice were deparaffinized, and an antigen retrieval procedure was performed by immersing the slides in citrate buffer ( $\mathrm{pH}$ 6.0) and heating in an autoclave at $110^{\circ} \mathrm{C}$ for $15 \mathrm{~min}$. After washing with phosphate-buffered saline (PBS), tissue sections were blocked with 5\% goat serum in PBS containing $0.05 \%$ Tween-20 for $10 \mathrm{~min}$, and the slides were incubated overnight at $4^{\circ} \mathrm{C}$ with anti-mouse $\mathrm{ER} \alpha$ (Santa Cruz Biotechnology, Inc., Santa Cruz, CA, USA), anti-mouse ERß (AnaSpec, San Jose, CA, USA), anti-mouse PR (Santa Cruz Biotechnology, Inc.), or anti-mouse FSHR (Santa Cruz Biotechnology, Inc.) rabbit polyclonal $\mathrm{IgG}$, respectively. After washing with PBS containing $0.05 \%$ Tween-20, the tissue sections were incubated for $1 \mathrm{~h}$ at room temperature with rhodamine-conjugated anti-rabbit IgG donkey antibody (Chemicon International, Inc., Temecula, CA, USA) for ER $\alpha$ and ERß, and with fluorescein isothiocyanate (FITC)conjugated anti-rabbit IgG goat antibody (SouthernBiotech, Birmingham, AL, USA) for PR and FSHR, washed again and mounted with glycerin solution containing 10\% PBS. Immunofluorescence images were observed under a fluorescence microscope (BX50; Olympus Corporation, Tokyo, Japan), using 520- to 550-nm excitation and $>580-\mathrm{nm}$ emission filters for the red color of rhodamine, or 470- to 490-nm excitation and 520- to 550-nm emission filters for the green color of FITC.

Ovum counting. Ova were collected from resected oviducts of the mice $12 \mathrm{~h}$ after hCG injection, and the number of ova was counted using a stereoscopic microscope (SZX-ZB12; Olympus Corporation).

Statistics. Differences between groups were compared by a non-parametric Mann-Whitney U test using StatView software, version 5.0 (SAS Institute Inc., Cary, NC, USA). P $<0.05$ was considered to be statistically significant. The results of the data analysis are shown in the figures as box-plots, for which $50 \%$ of the data are summarized in the box. The line in each box represents the median, and the lines outside each box represent the $90 \%$ confidence intervals.

\section{Results}

Serum estradiol concentration. The estradiol concentration in mouse serum was examined, and no significant difference
A

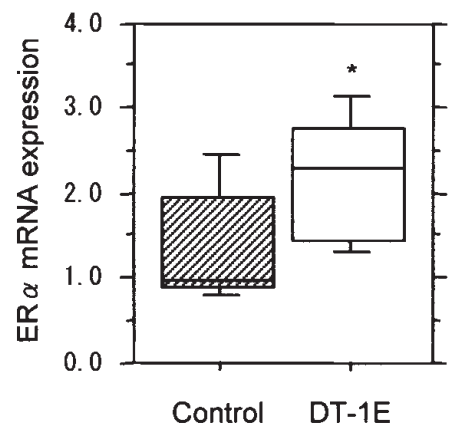

B

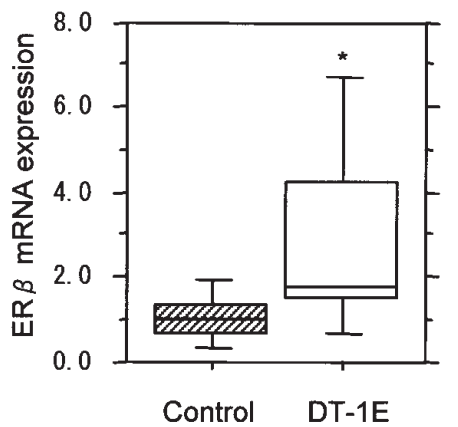

C

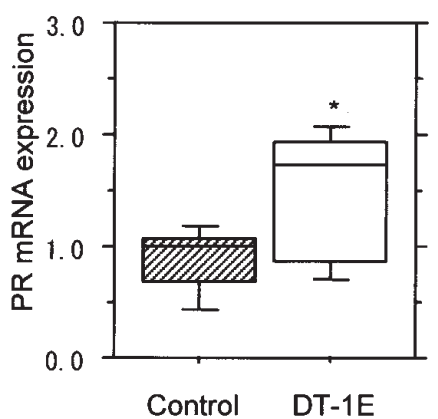

Figure 3. Expression of ER $\alpha, E R ß$ and PR mRNA in the uterus after gonadotropin injection. By TaqMan real-time RT-PCR assays, the expression of ER $\alpha$ (A), ERß (B) and PR (C) mRNA was significantly higher in the DT-1E group than that in the control group ( $\left.{ }^{*} \mathrm{P}<0.05\right)$, following gonadotropin injection. Values are expressed as fold-change compared to levels observed in the control group. 


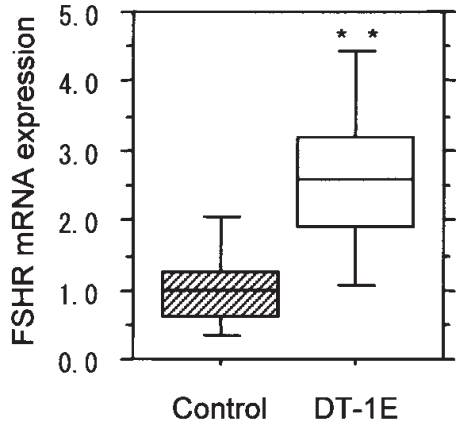

Figure 4. FSHR mRNA expression in the ovaries after gonadotropin injection. The expression of FSHR mRNA was found to be significantly higher in the DT-1E group than in the control group $\left({ }^{* *} \mathrm{P}<0.01\right)$ after the administration of gonadotropin injection, using TaqMan real-time RT-PCR. Values are expressed as fold-change compared to levels observed in the control group.

was found between the DT-1E and the control groups, either with or without gonadotropin injection. For mice without gonadotropin injection, the estradiol concentration in the control group was $9.3 \pm 1.8 \mathrm{pg} / \mathrm{ml}$, and that in the DT-1E group was $10.8 \pm 2.5 \mathrm{pg} / \mathrm{ml}$. For mice that underwent gonadotropin injection, the estradiol concentration was $12.3 \pm 6.5 \mathrm{pg} / \mathrm{ml}$ in the control group, and $12.4 \pm 4.4 \mathrm{pg} / \mathrm{ml}$ in the DT-1E group.

Quantitative analyses of ER a and ERß $m R N A$ expression in the adipose tissue and uterus. We examined the ER $\alpha$ and ERß mRNA levels in the adipose tissue and uteri of the mice fed a plain diet and without gonadotropin injection, using
TaqMan real-time RT-PCR. Based on the consistent RT-PCR efficiency of TaqMan commercial reagent cores, the results showed that the mRNA expression level for ER $\alpha$ was much higher than that for ER $\alpha$, both in the adipose tissue (Fig. 1A) and in the uteri (Fig. 1B) of mice.

Expression of ER $\alpha$ and ER $\beta$ in adipose tissue. Both $\mathrm{ER} \alpha$ and ERß mRNA in adipose tissue of mice without gonadotropin injection showed significantly higher expression in the DT$1 \mathrm{E}$ group than that in the control group by quantitative realtime RT-PCR assays $(\mathrm{P}<0.05)$ (Fig. 2). Immunofluorescence for estrogen receptors (ERs) in adipocytes was more prominent in the DT-1E group (Fig. 5B and D) than that in the control group (Fig. 5A and C).

Expression of $E R \alpha, E R \beta$, and $P R$ in uteri. No significant difference in the expression level of ER $\alpha, E R \beta$, or PR mRNA in the uteri was found between the DT-1E and control groups without gonadotropin injection. However, in the mice that received gonadotropin injection, the DT-1E group showed significantly higher levels of ER $\alpha, E R ß$ and PR mRNA expression in the uteri than the control group $(\mathrm{P}<0.05)$ (Fig. 3). Immunofluorescence for $E R \alpha, E R ß$ and $P R$ in uterus epithelial and stromal cells of mice with gonadotropin injection was more prominent in the DT-1E group (Fig. 6B, $\mathrm{D}$ and F) compared with the control group (Fig. 6A, C and E).

Comparison of FSHR expression in ovaries between groups. In the mice without gonadotropin injection, no significant difference was found in the expression level of FSHR mRNA
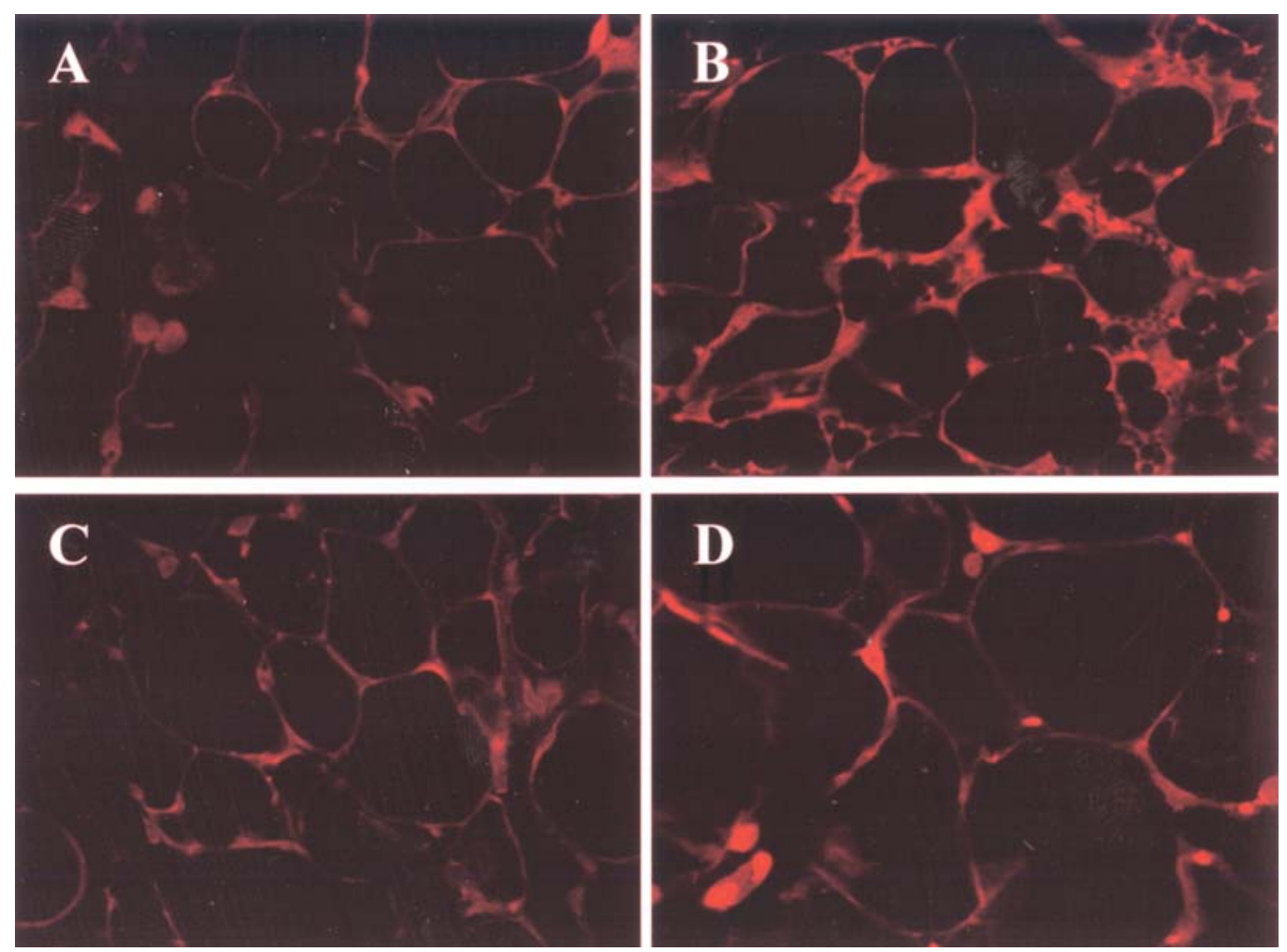

Figure 5. Fluorescence immunohistochemistry of ERs in adipose tissue. Adipose tissue of the control (A, C) and DT-1E (B, D) groups was reacted with anti$\mathrm{ER} \alpha(\mathrm{A}, \mathrm{B})$, or anti-ERß $(\mathrm{C}, \mathrm{D})$ rabbit IgG, and stained with rhodamine-conjugated anti-rabbit IgG antibody. The fluorescence in adipocytes for either ER $\alpha$ or ERß was more prominent in the DT-1E group than that in the control group. Magnification, $\mathrm{x} 400$. 

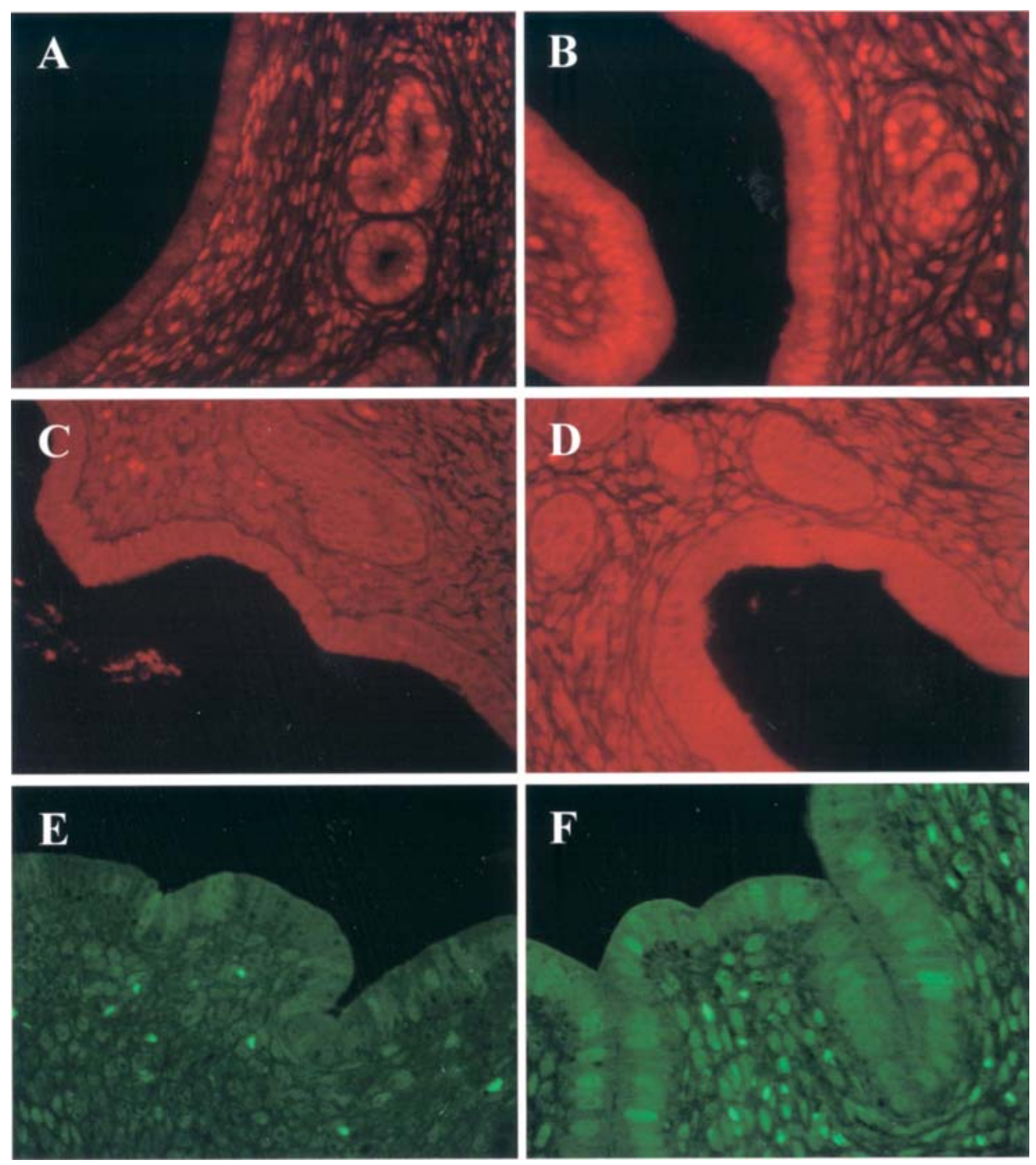

Figure 6. Fluorescence immunohistochemistry of ERs and PR in the uteri. Uteri of the control (A, C and E) and DT-1E (B, D and F) groups were reacted with anti-ER $\alpha(A, B)$, anti-ERß (C, D), or anti-PR (E, F) rabbit IgG, and stained with rhodamine-conjugated (ER $\alpha$ and ERß) or FITC-conjugated (PR) anti-rabbit $\operatorname{IgG}$ antibodies. The fluorescence for $\mathrm{ER} \alpha, \mathrm{ER} ß$ and PR was more prominent in the DT-1E group than that in the control group. Magnification, $\mathrm{x} 400$.
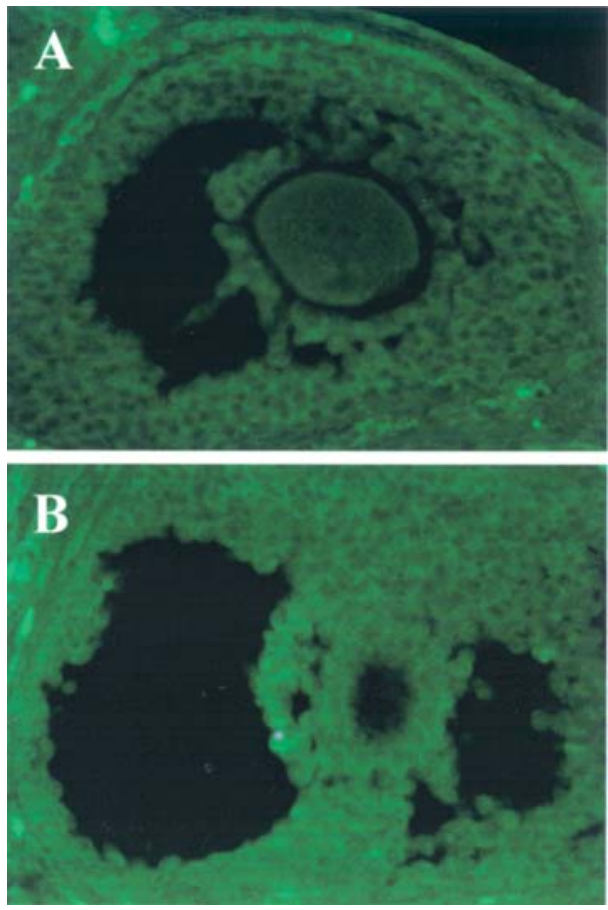

Figure 7. Fluorescence immunohistochemistry of FSHR in the ovaries. Ovaries of the control (A) and DT-1E (B) groups were reacted with antiFSHR rabbit IgG, and stained with FITC-conjugated anti-rabbit IgG antibody. The fluorescence in granulosa cells for FSHR was more prominent in the DT-1E group than that in the control group. Magnification, $\mathrm{x} 400$.

in the ovaries between the DT-1E and control groups. However, in mice that received gonadotropin injection, the DT-1E group showed a significantly higher level of FSHR mRNA expression in the ovaries than the control group $(\mathrm{P}<0.01)$ (Fig. 4). Immunofluorescence for FSHR in ovarian granulosa cells was more prominent in the DT-1E group (Fig. 7B) than that in the control group (Fig. 7A).

Ovum number in mice with gonadotropin injection. After the administration of gonadotropin injection, we collected the oviducts during dissection and counted the number of ova. The data showed that the DT-1E group (median=7) presented more ova than the control group (median $=5)(\mathrm{P}<0.05)$. 


\section{Discussion}

We chose the uterus and the ovary as target reproductive organs, and adipose tissue as a non-reproductive tissue expressing ERs, to investigate the effects of DT-1E in mice, including changes in hormone (estradiol) levels, receptor expression (ER $\alpha, \mathrm{ER} \beta, \mathrm{PR}$ and FSHR), and the reproductive function of ovulation following gonadotropin injection.

The estradiol concentration in mouse serum was examined by RIA, and no significant difference was found between the DT-1E and control groups, even after the administration of gonadotropin injection, which indicates that the effects of DT-1E are unlikely to be mediated through changes in circulating hormone levels.

Between groups, the DT-1E group showed significantly higher expression of ER $\alpha$ and ER $\beta$ in adipose tissue than did the control group. Reproductive hormones, such as estrogens, play important roles in adipose tissue metabolism (14), and it has been revealed that lipolysis in mice involves ER $\alpha(15,16)$. Although no difference in body weight and food intake in mice was found between the groups (data not shown), further investigation of the metabolism of adipose tissue is needed.

Without gonadotropin injection, no significant difference in $\mathrm{ER} \alpha, \mathrm{ER} \beta$ or PR expression in the uterus was found between the DT-1E and control groups. However, in mice that received gonadotropin injection, expression of ER $\alpha, E R \beta$ and PR was higher in the DT-1E group compared with the control group. These results indicate that although oral intake of DT-1E did not solely up-regulate the expression of ER and PR mRNA in the uterus, it enhanced the responsive capacity of the uterus.

Besides the above-mentioned findings, after the administration of gonadotropin injection, we obtained ova and compared their numbers between the groups. The DT-1E group presented more ova than the control group, which also suggests the functional effect of DT-1E on the reproductive system, including its effect of increasing FSHR expression. The present results on the expression of FSHR also indicate that DT-1E might enhance the responsive capacity of the ovary, although oral intake of DT-1E did not solely upregulate the expression of FSHR, similar to that in the uterus.

To date, many commercial herbal products are available for health care and clinical treatments; however, reports of such products that can augment hormone receptor expression are rare. Our present study highlights the up-regulating effect of DT-1E on the expression of reproductive hormone receptors in adipose tissues, uteri and ovaries of mice, suggesting great potential for clinical applications. As we know, HRT was introduced 20 years ago to relieve menopausal symptoms (17); however, HRT has recently become a topic of debate because subject-based studies have revealed a risk of breast cancer, endometrial cancer and coronary artery disease (18-20), recommending that the estrogen dose should be as low as possible $(4,19,21)$. This present study suggests that DT-1E up-regulates a series of reproductive hormone receptors, possibly enhancing their responsiveness and sensitivity to hormones, and might allow low estrogen doses for HRT to reduce these risks. In addition, the elevated ovulation function caused by gonadotropin injection indicates that DT-1E could be beneficial in women with ovulation dysfunction.
In conclusion, our study revealed up-regulation of $\mathrm{ER} \alpha$, $\mathrm{ER} \beta, \mathrm{PR}$ and FSHR expression by DT-1E following oral treatment in mice, and DT-1E may have great potential as an alternative way to treat reproductive hormone-related disturbances.

\section{Acknowledgements}

We would like to thank Wellness Advance Institute for the support of this research. We also thank the staff of Osaka City University Graduate School of Medicine for their technical assistance.

\section{References}

1. Buckler H: The menopause transition: endocrine changes and clinical symptoms. J Br Menopause Soc 11: 61-65, 2005.

2. Lovejoy JC: The menopause and obesity. Prim Care 30: 317-325, 2003.

3. Henderson BE and Feigelson HS: Hormonal carcinogenesis. Carcinogenesis 21: 427-433, 2000.

4. Jacobs HS: Hormone replacement therapy and breast cancer. Endocr Relat Cancer 7: 53-61, 2000.

5. Gambacciani M and Genazzani AR: Hormone replacement therapy: the benefits in tailoring the regimen and dose. Maturitas 40: 195-201,2001.

6. Tsai MJ and O'Malley BW: Molecular mechanisms of action of steroid/thyroid receptor superfamily. Annu Rev Biochem 63: 451-486, 1994.

7. Gether U: Uncovering molecular mechanisms involved in activation of G protein-coupled receptors. Endocr Rev 21: 90-113, 2000 .

8. Albertazzi P: Alternatives to estrogen to manage hot flushes. Gynecol Endocrinol 20: 13-21, 2005.

9. Newton KM, Reed SD, Grothaus L, Ehrlich K, Guiltinan J, Ludman E and Lacroix AZ: The herbal alternatives for menopause (HALT) study: background and study design. Maturitas 52: 134-146, 2005.

10. Schutz K, Carle R and Schieber A: Taraxacum - a review on its phytochemical and pharmacological profile. J Ethnopharmacol 107: 313-323, 2006.

11. Yuan JS, Reed A, Chen F and Stewart CN Jr: Statistical analysis of real-time PCR data. BMC Bioinformatics 7: 85, 2006.

12. Pfaffl MW: A new mathematical model for relative quantification in real-time RT-PCR. Nucleic Acids Res 29: e45, 2001.

13. Livak KJ and Schmittgen TD: Analysis of relative gene expression data using real-time quantitative PCR and the 2- $\triangle \Delta C T$ method. Methods 25: 402-408, 2001.

14. Darimont C, Delansorne R, Paris J, Ailhaud G and Negrel R: Influence of estrogenic status on the lipolytic activity of parametrial adipose tissue in vivo: an in situ microdialysis study. Endocrinology 138: 1092-1096, 1997.

15. Rodriguez-Cuenca S, Monjo M, Proenza AM and Roca P: Depot differences in steroid receptor expression in adipose tissue: possible role of the local steroid milieu. Am J Physiol Endocrinol Metab 288: E200-E207, 2005.

16. Heine PA, Taylor JA, Iwamoto GA, Lubahn DB and Cooke PS: Increased adipose tissue in male and female estrogen receptoralpha knockout mice. Proc Natl Acad Sci USA 97: 12729-12734, 2000.

17. Nichols KC, Schenkel L and Benson H: 17 beta-estradiol for postmenopausal estrogen replacement therapy. Obstet Gynecol Surv 39: 230-245, 1984.

18. Stevenson JC: Hormone replacement therapy: review, update, and remaining questions after the Women's Health Initiative Study. Curr Osteoporos Rep 2: 12-16, 2004.

19. Emons G, Huschmand-Nia A, Krauss T and Hinney B: Hormone replacement therapy and endometrial cancer. Onkologie 27: 207-210, 2004.

20. Timins JK: Current issues in hormone replacement therapy. N J Med 101: 21-27, 2004.

21. Peeyananjarassri K and Baber R: Effects of low-dose hormone therapy on menopausal symptoms, bone mineral density, endometrium, and the cardiovascular system: a review of randomized clinical trials. Climacteric 8: 13-23, 2005. 